\title{
Reaction kinetics of lactic acid fermentation from bitter cassava (Manihot glaziovii) starch by Lactobacillus casei
}

\author{
Setiyo Gunawan ${ }^{*}$, Nurul Rahmawati, Rona Bening Larasati, Ira Dwitasari, Hakun Wirawasista Aparamarta, Tri Widjaja \\ Department of Chemical Engineering, Institut Teknologi Sepuluh Nopember, Jl. Teknik Kimia, Keputih, Kota Surabaya, Jawa Timur 60111, \\ Indonesia \\ ${ }^{*}$ Corresponding author: gunawan@chem-eng.its.ac.id
}

SUBMITTED 8 February 2020 REVISED 5 July 2020 ACCEPTED 25 November 2020

\begin{abstract}
One of the utilizations of bitter cassava is modified cassava flour (Mocaf) production using the fermentation process by Lactobacillus casei. The Mocaf has potential as the future of food security products. It has a characteristic property similar to wheat flour. Lactic acid was also produced as a by-product during fermentation. After $40 \mathrm{~h}$ of fermentation, the proximate composition content of Mocaf was lactic acid content of $0.000928 \mathrm{~g} / \mathrm{L}$, hydrogen cyanide levels of $0.02 \mathrm{ppm}$, starch content of $59.13 \%$, amylose content of $12.98 \%$ and amylopectin content of $46.15 \%$. In the scaling-up process from a laboratory scale to a pilot and industrial scale, modeling is needed. There are five equation models used to describe the kinetic reactions of lactic acid from bitter cassava starch: Monod, Moser, Powell, Blackman, and Product Inhibitor. Each parameter was being searched by a fitting curve using sigmaplot 12.0 . The best result in terms of the highest $\mathrm{R}^{2}$ (0.65913) was obtained in the Powell equation with the value of $\mu$ max of $1.668 / \mathrm{h}$, Ks of $123.4 \mathrm{~g} / \mathrm{L}$, and maintenance rate (m) of 4.672. The kinetic data obtained can be used to design biochemical reactors for industrial scale Mocaf flour production.
\end{abstract}

KEYWORDS Kinetic model; lactic acid; Lactobacillus casei; Mocaf

\section{Introduction}

Modified cassava flour (Mocaf) is a cassava flour product, in which cassava is processed using the principle of lactic acid fermentation to improve the nutritional content (Gunawan et al. 2019). Abundant raw materials, inexpensive, easily obtained, and the processing that does not require high technology makes Mocaf the best alternative for wheat flour substitutes (Gunawan et al. 2017). Besides, the production of Mocaf with the principle of lactic acid fermentation using lactic acid bacteria, produces a by-product in the form of lactic acid (Istianah et al. 2018).

In previous studies, the production of modified cassava flour without additional nutrients at an appropriate microorganism (Lactobacillus plantarum, Saccharomyces cereviseae, and Rhizopus oryzae) obtained the best results of Mocaf flour in fermentation using L. plantarum (Gunawan et al. 2015). The use of L. plantarum bacterial culture in cassava (Manihot esculenta; "singkong” in Indonesia) (Gunawan et al. 2015), sorghum (Sorghum bicolor L. Moench; “sorgum” in Indonesia) (Istianah et al. 2018), sago (Metroxylon sago; “sagu” in Indonesia) (Gunawan et al. 2018), and yam (Dioscorea hispida Dennst; “gadung” in Indonesia) (Gunawan et al. 2019) fermentations has been widely used in previous studies, so researchers are interested in using other bacterial starters (such as Lactobacillus casei) that are easily obtained and easily adaptable. $L$. casei is a lactic acid-producing bacteria, obtained by glucose fermentation and the production of homofermentative lactate produces pure lactate nearly $85 \%$, and also able to ferment ribose into acetic and lactic acid (Farinde et al. 2010). Moreover, L. plantarum and L. casei have differences in their growth rates (growth velocity constants) at the basal media. The growth rate constant of $L$. plantarum and $L$. casei was 0.13 cell/h and 0.16 cell/h, respectively (Zacharof et al. 2009).

To understand the process of lactic acid fermentation by L. casei, a fermentation kinetics study is needed which describes cell growth and product formation by microbes. The kinetic model is a useful parameter in the design and control of biotechnology processes to increase knowledge about microbial growth behavior using accurate mathematical models in detailed repeated experiments. Mahanta et al. (2014) have researched the microbial growth kinetics of Escherichia coli on glucose growth media. Previously, Rezvani et al. (2017) were also using the Contois and Exponential kinetic models. They reported that Contois kinetic model is a suitable model to describe the kinetics of five species of Lactobacillus. Therefore, the objective of this study was to study the reaction kinetics of lactic acid fermentation from bitter cassava (Manihot glaziovii) 
by L. casei. The parameters of the kinetic equation models, such as Monod, Moser, Powell, Blackman, and Product inhibitor was also investigated systematically using the fitting curve method.

\section{Materials and Methods}

\subsection{Material}

Bitter cassava (M. glaziovii) was obtained from Sragen Regency, Central Java, Indonesia. It has an average planting age of more than one year with an average tuber diameter reaching $10 \mathrm{~cm}$. L c casei bacteria obtained from the Microbiology Laboratory of the Department of Biology, Airlangga University, Surabaya. All solvents and reagents were purchased from commercial sources.

\subsection{Starter Preparation}

In this study, the starter used was $5.2 \mathrm{~g}$ of MRS dissolved in $100 \mathrm{~mL}$ distilled water. A full loop of $L$. casei bacteria was added to the Erlenmeyer flask containing the media. Furthermore, the starter was incubated in a shaker incubator at a speed of $150 \mathrm{rpm}$ at $37^{\circ} \mathrm{C}$ for $24 \mathrm{~h}$.

\subsection{Pre-Treatment}

Pre-treatment was done by cutting $130 \mathrm{~g}$ of cassava then cut into slices chips with a thickness of $0.1-0.5 \mathrm{~cm}$. This cutting process aims to expand the contact surface between bitter cassava and water. Cassava was washed 3 times then was soaked with the weight ratio of cassava to soaking water volume of 1:10 (cassava: water) for $90 \mathrm{~min}$ to reduce HCN levels at room temperature. This method was adopted from Nebiyu and Getachew (2011) by modifying the fermentation time.

\subsection{Fermentation}

In this study, the fermentation method used was the submerged fermentation. One hundred and thirthy grams of cassava that had been pretreated was put into an Erlenmeyer flask containing $260 \mathrm{~mL}$ of distilled water. Then, a starter was added as much as $28 \mathrm{~mL}$ (10\% of the total work volume) (Panesar et al. 2010). To obtain anaerobic conditions, the surface of the Erlenmeyer was closed using cotton and aluminum foil. Fermentation was done at $37^{\circ} \mathrm{C}$ for $40 \mathrm{~h}$ in a shaker incubator. After $40 \mathrm{~h}$, the fermentation was stopped then the cassava was separated from the fermentation liquid for further drying and mashing according to flour standards (80 mesh).

\subsection{Proximate Analysis}

The proximate analysis consists of protein, starch, amylose, and amylopectin contents. Protein content was analyzed by using the AOAC (2005) procedure, while starch, amylose, and amylopectin contents were determined by using the Indonesian National Standard (SNI) procedure (SNI 2011).

\subsection{Hydrogen Cyanide (HCN) Analysis}

HCN content was analyzed based on SNI (2011). The step was began with distillation process of $20 \mathrm{~g}$ samples during 2-4 h. Then, distillate was titrated by solution of $\mathrm{AgNO}_{3}$ $0.02 \mathrm{M}$. Calculation of HCN levels was using the following equation:

Cyanide acid content $(\mathrm{mg} / \mathrm{kg})=(V 1-V 2) \times N \times\left(\frac{27}{V 3 \times W}\right)$

where V1, V2, V3, N, and $\mathrm{W}$ is the blank titration reading, sample titration reading, distillate volume, $\mathrm{AgNO}_{3}$ normality, and sample weight, respectively. The value of 27 is the molecular weight of cyanide acid.

\subsection{Lactic Acid Analysis}

Product measurements of lactic acid concentration were determined using the Total Titratable Acidity (TTA) method in GEA (2006). A total of $2 \mathrm{~mL}$ of sample was added with three drops of PP indicator then titrated using $0.2 \mathrm{~N} \mathrm{NaOH}$ solution until it turned pink. Lactic acid content was calculated by the following formula:

$$
\text { Lactic acid levels }(\mathrm{mg} / \mathrm{mL})=N \times V 1 \times\left(\frac{0.090}{V 2}\right)
$$

where $\mathrm{N}, \mathrm{V} 1$, and $\mathrm{V} 2$ is $\mathrm{NaOH}$ normality, $\mathrm{NaOH}$ volume, and sample volume, respectively. Whereas 0.090 is the milliequivalent of lactic acid.

\section{8. $p H$ Analysis}

Two mililiter samples were taken from an Erlenmeyer flask using a pipette, then the $\mathrm{pH}$ was analyzed using a digital $\mathrm{pH}$ meter electrode (Eutech, Singapore). Before using a digital $\mathrm{pH}$ meter, it was calibrated first.

\subsection{Analysis of Microbial Number}

The number of microbes was analyzed by using the method of counting chamber hemocytometer. Briefly, 1 $\mathrm{mL}$ of the fermentation solution was diluted with a 1,000 dilution factor. Then, it was dropped on a hemocytometer and was covered with deck glass. The number of bacteria calculation was done under a microscope (Novel, China).

\section{Results and Discussion}

\subsection{Cell growth}

Growth is one of the important characteristics of microorganisms in fermentation. The increased number of $\mathrm{L}$. casei bacteria can be expressed as cell growth. Growth dynamics are displayed in a curve of increasing cell number with incubation time which can describe the phases of the bacterial growth cycle. The first bacterial growth cycle is the adaptation phase (lag), the phase of bacteria adjusting to the new environment, in this phase the cell increase in size but not in the number. The second is the exponential phase (log), the phase that bacterial propagation takes place rapidly, the cell is divide and the number increases logarithmically according to time increase. Then, the stationary phase is a balanced state between the rate of growth 
with the rate of death and finally the phase of death where the rate of bacterial death exceeds the rate of propagation (Gunawan et al. 2015).

The bacterial growth phase was used to determine the incubation time during the making of a starter in the lactic acid fermentation process. Bacterial growth was observed by analyzing the calculation of the cell number per hour during the $48 \mathrm{~h}$ incubation time by the counting chamber method. This tool can be used to count the cell number per unit volume.

The growth of $L$. casei for $48 \mathrm{~h}$ incubation at $37^{\circ} \mathrm{C}$ in MRS media is shown in Figure 1. From the results of the observations of the number of bacteria, the adaptation phase (lag) has occurred at the $0 \mathrm{~h}$ to the $4^{\text {th }} \mathrm{h}$, the exponential phase (log) has occurred at the $5^{\text {th }}$ to the $24^{\text {th }} \mathrm{h}$, and the stationary phase has occurred at the $25^{\text {th }}$ to the $48^{\text {th }} \mathrm{h}$. The growth of lactic acid bacteria was strongly influenced by fermentation conditions, such as temperature, $\mathrm{pH}$, medium components, and oxygen. Among all factors, the type of growth media played an important role in bacteria viability. This media difference was also the cause of the difference in the growth phase curve in the starter with MRS media and the growth curve resulting from the fermentation process using bitter cassava media. From Figure 1, it can be seen that $\mathrm{L}$. casei had a shorter lag phase, from 0 to $2 \mathrm{~h}$, log phase from 2 to $24 \mathrm{~h}$, and stationary phase from 24 to $40 \mathrm{~h}$.

In this study, the growth phase of $L$. casei was different from previous studies by Suharyono et al. (2012) who cultured $L$. casei on skim milk media the log phase occurred on the $8^{\text {th }}$ h to the $16^{\text {th }} \mathrm{h}$. Whereas Rezvani et al. (2017) reported that the log phase occurred on the $6^{\text {th }} \mathrm{h}$ to the 24th h with whey milk fermentation media. The difference growth phase can be caused by differences in the media used in bacterial culture. However, research by Panesar et al. (2010) that also using MRS media the log phase occurred on the $8^{\text {th }} \mathrm{h}$ to the $24^{\text {th }} \mathrm{h}$. This difference was due to the greater concentration of media used which was 0.2 $\mathrm{g} / \mathrm{mL}$ while in this study the concentration of MRS media used was $0.052 \mathrm{~g} / \mathrm{mL}$. This is consistent with the theory of microorganisms that are inoculated from a medium with low concentration to a medium with a higher concentration will require a longer lag phase since cells must produce enzymes for use.

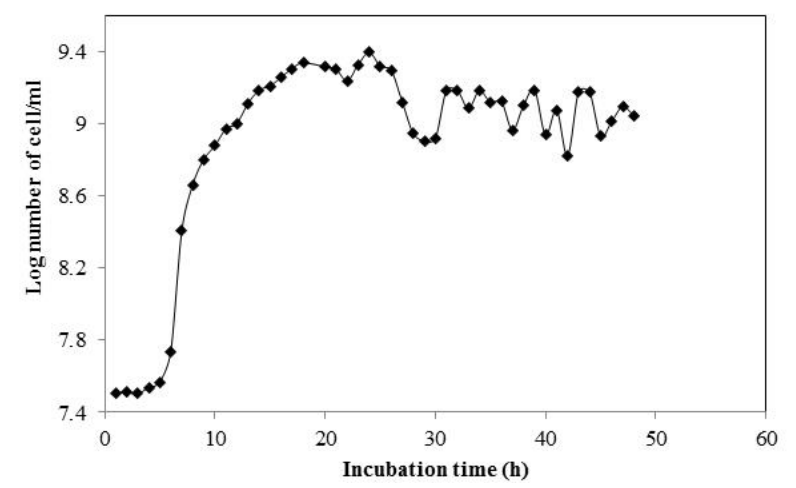

(a)

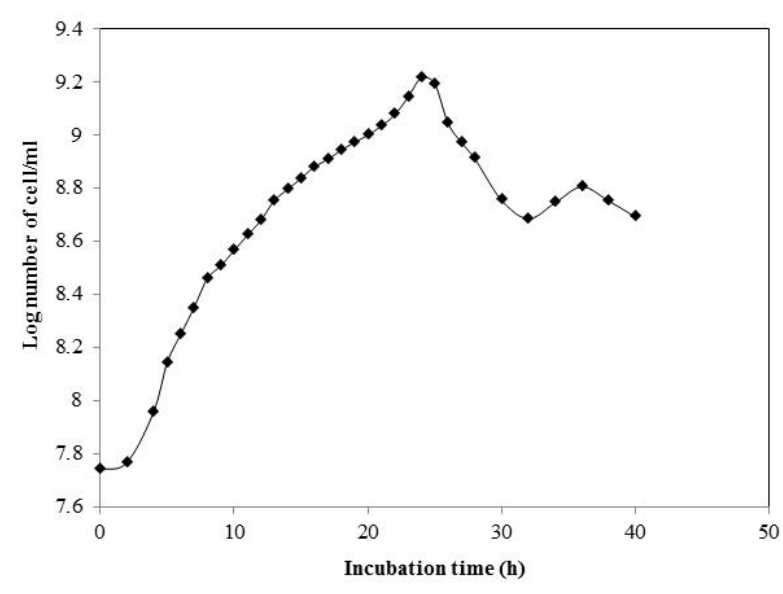

(b)

FIGURE 1 Microbial growth in MRS media (a) and bitter cassava media (b).

From the known growth phase, then it was used to determine the incubation time for the fermentation starter. The time chosen was at the peak of the log phase, on the $24^{\text {th }} \mathrm{h}$ where the bacteria have the biggest log which is 9.4 with the number of bacteria reaching $2.48 \times 10^{9}$ cells $/ \mathrm{mL}$ so that when regenerated on the new fermentation media, the number of cells produced was increased.

\subsection{Effect of pretreatment and fermentation time on HCN concentrations}

The purpose of pre-treatment is to reduce the concentration of HCN from bitter cassava so it can help the work of the

TABLE 1 Curve fitting using sigmaplot 12.0 on various kinetics equation models.

\begin{tabular}{lllll}
\hline Model & $\mathrm{R}^{2}$ & $\mu \max \left(\mathrm{h}^{-1}\right)$ & $\mathrm{Ks}(\mathrm{g} / \mathrm{L})$ & $\mathrm{m}$ \\
\hline Powell & 0.65913 & 1.668 & 123.4 & 4.672 \\
Moser & 0.35809 & 2.577 & $51,650,000$ & 2.514 \\
Blackman & 0.1638 & 0.0021 & 5.37 & $52,529,762.7$ \\
Monod & 0.1638 & $20,489.7$ & $46,150,168.3$ & \\
\hline & 0.1837 & $25,291.4$ & 9.5 \\
Product Inhibitor & 0.2044 & $75,750.670$ & 1 & 1.5 \\
& 0.2204 & $217,289.4$ & $197,542,069.3$ & 2 \\
\hline
\end{tabular}




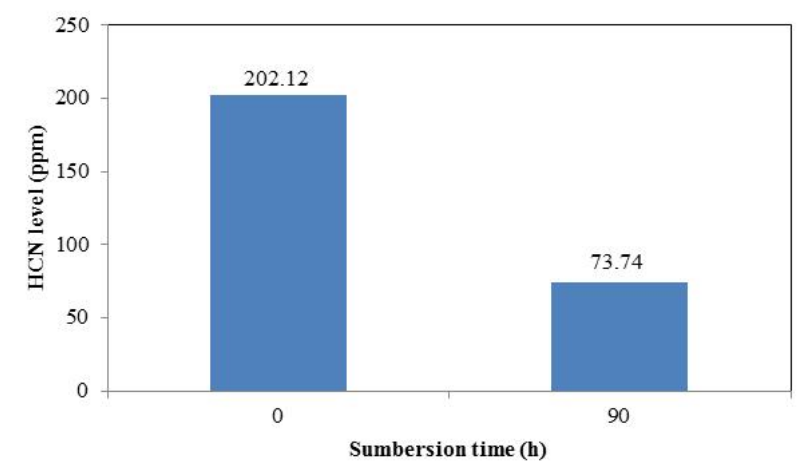

(a)

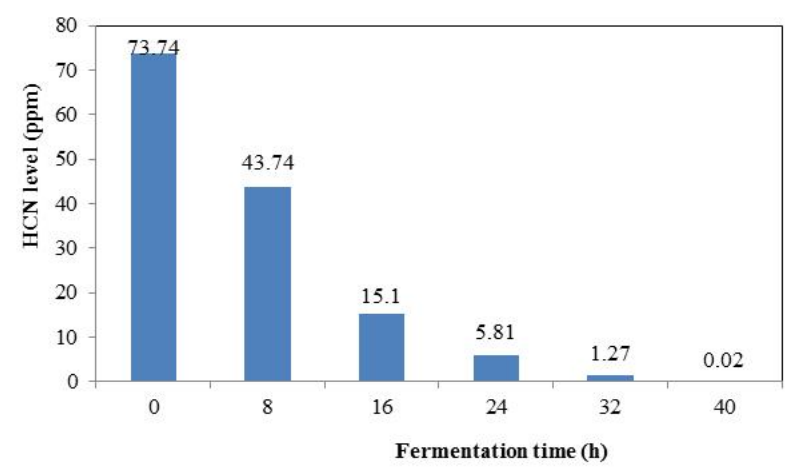

(b)

FIGURE 2 The effect of submersion time (a) and fermentation time (b) on $\mathrm{HCN}$ concentration

bacterium $L$. casei in the next process (fermentation). Data analysis of HCN concentration in bitter cassava after pretreatment can be seen in Figure 2. It can be seen that there was a decrease in the concentration of HCN in bitter cassava by $63.52 \%$, from $202.12 \mathrm{ppm}$ to $73.74 \mathrm{ppm}$. This was consistent with research by Nebiyu and Getachew (2011) which showed that there was a decrease in HCN concentration after soaking using water for $24 \mathrm{~h}$ by $90.01 \%$, from 108.37 ppm to 10.83 ppm. The decrease in HCN concentration is due to the nature of HCN which is easily soluble in water. This lower result is due to the shorter soaking time, which is $1.5 \mathrm{~h}$ compared to the study conducted by Nebiyu and Getachew (2011) where the soaking was carried out for $24 \mathrm{~h}$.

In the soaking process, the linamarin compound is hydrolyzed to form cyanide acid which is easily soluble in water. The difference in the concentration of the solution inside the bitter cassava cell with the solution outside the cell allows osmosis during the soaking process. In this case, the concentration of the solution outside the cell was smaller than inside the cell (hypotonic) so that water entered the cell and caused the cell to expand where the hydrolyzed linamarin formed cyanide acid which is easily soluble in water and volatile so the linamarin levels can be lowered through the soaking process. Therefore, it is necessary to soak the bitter cassava first to reduce HCN concentrations to ease the next process.

In Figure 3, it can be seen that HCN concentration

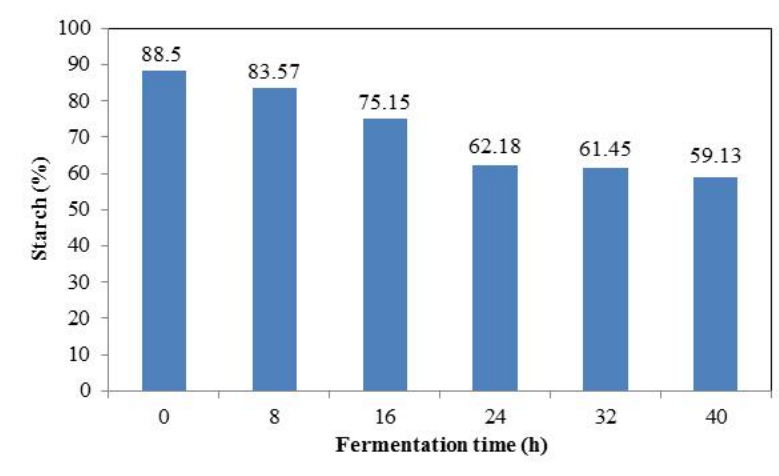

(a)

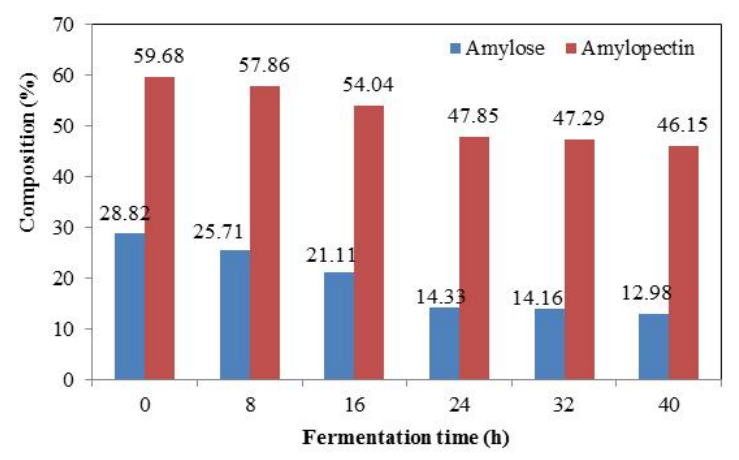

(b)

FIGURE 3 The effect of fermentation time on starch content (a) and amylose-amylopectin concentration (b).

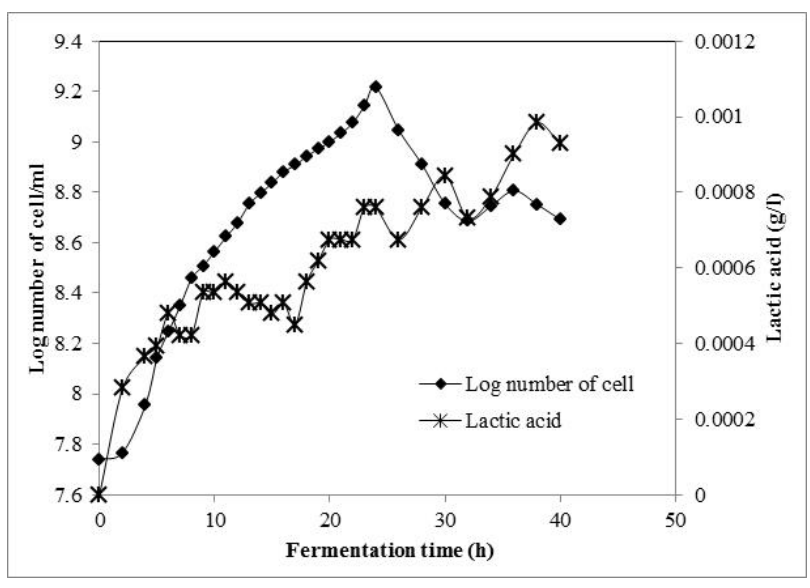

FIGURE 4 Relationship between number of cell with lactic acid production.

in modified cassava flour had also decreased. Starting with an initial HCN content of 73.74 ppm, the HCN content decreased by $40.68 \%, 79.66 \%, 92.12 \%, 98.28 \%$, and $99.97 \%$ after fermentation time of $8,16,24,32$, and $40 \mathrm{~h}$, respectively. This was consistent with previous research by Gunawan et al. (2015) that after $120 \mathrm{~h}$ of fermentation the HCN concentration in cassava decreased. The lowest HCN concentration was obtained after fermenting cassava using L. plantarum $(1.80 \pm 0.03 \mathrm{mg} / \mathrm{kg})$, S. cerevisiae (3.28 $\pm 0.01 \mathrm{mg} / \mathrm{kg})$, and $R$. oryzae $(3.17 \pm 0.04 \mathrm{mg} / \mathrm{kg})$. The 


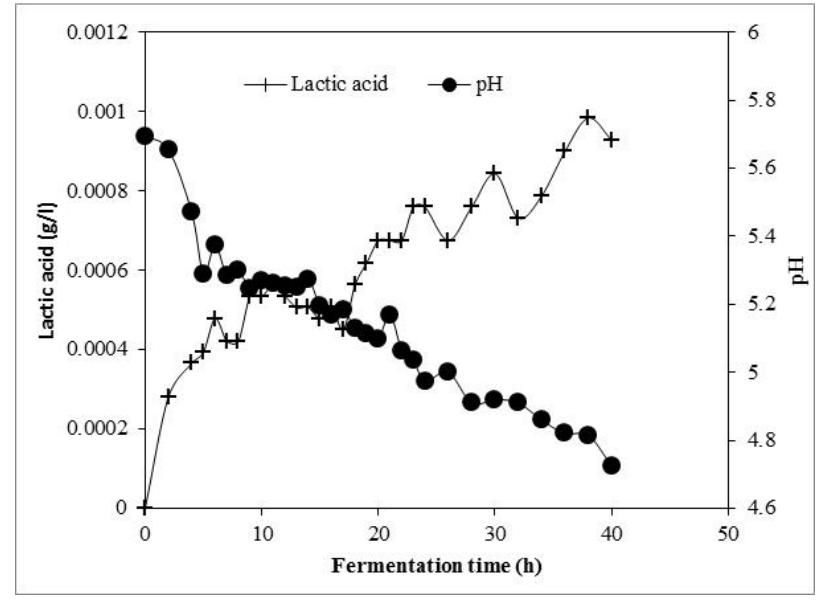

FIGURE 5 Effect of lactic acid production on $\mathrm{pH}$.

fermentation process by microorganisms can convert glucose into organic acids, causing $\mathrm{pH}$ to decrease to \pm 4.2 . On the other hand, optimum laminarase enzyme activity at $\mathrm{pH}$ 6.0. This low $\mathrm{pH}$ condition can reduce the activity of linamarase enzyme to decrease linamarin which will turn into cyanide acid.

\subsection{Effect of fermentation time on starch content}

Starch is microscopic granules found in roots, tubers, and seeds of plants. Starch consists of two separable fractions, the dissolved fraction is called amylose and the insoluble fraction is called amylopectin. Starch usually contains about $20-30 \%$ amylose and $70-80 \%$ amylopectin, but the amylose content can range from $<1 \%$ in waxy starch and $>$ $70 \%$ in certain high amylose starch (Martens et al. 2018).

The effect of fermentation time on starch content is shown in Figure 4. It can be seen that the starch content of modified cassava flour has decreased. Starting with an initial starch content of $88.50 \%$, the starch content decreased by $5.57 \%, 15.08 \%, 29.74 \%, 30.56 \%$, and $33.19 \%$ after fermentation time of $8,16,24,32$, and $40 \mathrm{~h}$, respectively. It was found that the longer the fermentation time, the lower the starch content was obtained. This is consistent with the research by Gunawan et al. (2015), after $120 \mathrm{~h}$ of fermentation, the starch content in cassava decreased. The lowest starch content was obtained after fermenting cassava using L. plantarum (55.40\%), S. cerevisiae $(71.03 \%)$, and R. oryzae (48.20\%). Decreasing starch content is caused by the use of organic materials to fulfill the energy needed for the growth of microorganisms. It is known that during the fermentation process, starch is hydrolyzed into simpler sugars from oligosaccharides and maltose to glucose. Furthermore, glucose is converted to lactic acid (Gunawan et al. 2015).

\subsection{Effects of fermentation time on amylose and amy- lopectin concentrations}

Starch usually contains about 20-30\% amylose and amylopectin by $70-80 \%$. Amylose is a linear polymer with $\alpha$ - $(1,4) \mathrm{D}$-glucopyranose bonds. Amylose molecules have more than 1000 glucose units. The chain of the D-glucose unit with $\alpha$-glycosidic tends to form a helix structure (Solomons and Craig 2011). While amylopectin has a larger structure than amylose, it consists of about 106 glucose units per molecule and forms a complex structure. Amylopectin consists of a linear chain of glucose units connected by $\alpha-1,4$ glycosidic bonds and is very branched in the $\alpha-1$ position, 6 (Alcázar-Alay and Meireles 2015).

Based on Figure 5, it can be seen that when the variable time increased, the amylose concentration decreased. The results obtained with bacterial concentrations of $5.5 \times 10^{7}$ cells/mL L casei. Starting with an initial amylose concentration of $28.82 \%$, the amylose concentration decreased by $10.79 \%$, 26.75\%, 50.28\%, 50.87\%, and 54.96\% after fermentation time of $8,16,24,32$, and $40 \mathrm{~h}$, respectively. It also can be seen that when the time variable increases, the amylopectin concentration decreases. The results obtained with a bacterial concentration of $5.5 \times 10^{7}$ cells $/ \mathrm{mL}$ L. casei. Starting with an initial amylopectin concentration of $59.68 \%$, the amylopectin concentration decreased by $3.05 \%, 9.45 \%, 19.82 \%, 20.76 \%$, and $22.67 \%$ after fermentation time of $8,16,24,32$, and $40 \mathrm{~h}$, respectively.

From these data, it shows that the longer the fermentation time, both the amylose concentration and the amylopectin concentration decreased. In a study by Setiarto and Nunuk (2017) fermentation using $L$. plantarum with a concentration of $10^{8} \mathrm{CFU} / \mathrm{mL}$ for $24 \mathrm{~h}$ showed amylose concentration decreased from $21.57 \%$ to $16.29 \%$ (a decrease of $24.48 \%$ ) whereas for amylopectin concentration decreased from $83.19 \%$ to $73.80 \%$ (a decrease of $11.29 \%$ ).

\subsection{Analysis of changes in lactic acid levels with Total Titratable Acidity (TTA)}

Lactic acid is a carboxylic acid that has the isomeric form of $\mathrm{L}(+)$ or $\mathrm{D}(-)$ lactic acid. Lactic acid has a molecular formula $\mathrm{CH} 3 \mathrm{CHOHCOOH}$. There are two ways to produce lactic acid, either by chemical synthesis or by fermentation. The fermentation process produces specific lactic acid: $\mathrm{L}(+)$ lactic acid or $\mathrm{D}(-)$ lactic acid while the chemical synthesis process produces lactic acid which is a mixture of two isomers (Narayanan et al. 2004). L(+) lactic acid is the isomer chosen for the food and pharmaceutical industries because the human body only produces the enzyme L-lactate dehydrogenase.

For the food and beverage industries, lactic acid levels of $50-80 \%$ are usually required, whereas for the pharmaceutical industry required higher levels of $85-90 \%$. $L$. casei is a lactic acid-producing bacteria, obtained by glucose fermentation and homofermentative lactate formation forming pure lactate nearly $85 \%$, this bacterium is also able to ferment ribose into acetic acid and lactic acid (Farinde et al. 2010). Based on research by Mirdamadi et al. (2002) among the strains of lactobacilli, L. casei (casei PTCC 1608) produced high concentrations of L (+) lactic acid with a purity of $98 \%$. To analyze the amount of lactic acid produced from the fermentation process the Total Titratable Acidity (TTA) method is used. This method has standard procedures from GEA (2006). 


\subsubsection{Effect of microbial growth on lactic acid prod- ucts}

Based on Figure 4, the production of lactic acid from bitter cassava fermentation (M. glaziovii) was very volatile but tends to increase with increasing numbers of bacteria. This was consistent with the research by Alvarez et al. (2010), that the concentration of lactic acid increases with the increase in the number of microbes and a decrease in glucose levels as a substrate. At the end of the fermentation, the lactic acid concentration reached $>50 \mathrm{~g} / \mathrm{L}$ with a yield of $1.8 \mathrm{~g}$ of lactic acid/g of biomass. While the peak production of lactic acid in this study occurred at the 38th h with a concentration of $0.000984 \mathrm{~g} / \mathrm{L}$ on the number of bacteria of $5.675 \times 10^{8}$.

The type and condition of the media determine the type and ability of lactic acid bacteria to ferment starch as a substrate for growth. For the batch fermentation lactic acid bacteria, a previous study by Bai et al. (2003) comparing the yield of lactic acid produced from different carbon sources such as glucose, lactose, and xylose. The best results were obtained glucose as a substrate with a concentration of $150.2 \mathrm{~g} / \mathrm{L}$ with lactic acid produced at $1.34 \mathrm{~g} / \mathrm{L}$. From five types of microbes that were compared, Lactobacillus bulgaricus was the microbe that produced the best lactic acid yield of 0.602 (Rezvani et al. 2017). So it can be concluded that the differences in substrate and type of microbes greatly affect the lactic acid produced in the fermentation process.

Lactic acid bacteria require substrates with high nitrogen content. Sources of nitrogen needed in the fermentation media can be supplied with additional yeast extract, soy flour, tryptone, and peptone. Whereas in the process of bitter cassava fermentation by $L$. casei there was no treatment to add a source of nitrogen during the fermentation, as a result, the bacteria lacked the element nitrogen so that the production of lactic acid was very small. The results of research by Taleghani et al. (2016) stated that the production of lactic acid increased with increasing concentrations of added yeast extract. Optimum results are obtained by adding $1 \%$ yeast extract with a yield of $29.5 \mathrm{~g} / \mathrm{L}$ lactic acid and a yield of $79.5 \%$.

\subsection{Effect of lactic acid products on changes in $\mathrm{pH}$}

Changes in lactic acid production are associated with changes in the level of acidity of the media $(\mathrm{pH})$. The $\mathrm{pH}$ measurement was carried out simultaneously with the measurement of the amount of lactic acid using a $\mathrm{pH}$ meter. Based on Figure 5, the fermentation of bitter cassava (M. glaziovii) by L c casei caused a decrease in $\mathrm{pH}$ and results in a pattern of lactic acid production which fluctuated but tended to increase. The measured $\mathrm{pH}$ value showed a decrease in following the rate of increase in the amount of lactic acid. An increase in lactic acid in low concentrations can affect the rate of dissociation of $\mathrm{H}^{+}$ions so that it results in changes in media $\mathrm{pH}$.

According to Krischke et al. (1991), the optimum pH for producing lactic acid using the $L$. casei strain was in the
$\mathrm{pH}$ range of 6.0-6.5, whereas in this study the measured $\mathrm{pH}$ was in the range of 5.69-4.73. This is thought to be one of the factors affecting the low lactic acid formed. Initially, an increase in lactic acid is followed by a decrease in $\mathrm{pH}$, but in the log phase, an increase in total lactic acid is not always followed by a decrease in $\mathrm{pH}$, during this phase the total measured lactic acid is very volatile. The rate of decrease in $\mathrm{pH}$ continues until it reaches a $\mathrm{pH}$ of 4.73 at the end of the incubation period $\left(40^{\text {th }} \mathrm{h}\right)$, as well as the rate of increase in lactic acid, continues to occur until an insignificant decrease at the $40^{\text {th }} \mathrm{h}$.

\subsection{Analysis of the growth kinetics of $L$. casei}

The non-linear kinetic models of Powell, Moser, Blackman, Monod, and Product Inhibitor were fitting with the correlation between the growth rate of $L$. casei bacteria and the concentration of the substrate as shown in equation 3, 4, 5, 6, and 7, respectively. The parameters of each model were estimated by the curve fitting method using the Sigmaplot 12.0 software. They are specific growth rate $\left(\mathrm{h}^{-1}\right), \mu_{\mathrm{m}}$ specific growth rate maximum $\left(\mathrm{h}^{-1}\right)$, Ks saturated substrate constant (g/L), S substrate concentration (g/L), m maintenance rate, Cp product concentration (g/L), Cpm Maximum product concentration (g/L), and n number of cell.

$$
\begin{gathered}
\mu=\frac{\left(\mu_{m}+m\right) S}{k_{s}+S}-m \\
\mu=\frac{\mu_{m} S^{n}}{k_{s}+S^{n}} \\
\mu= \begin{cases}\frac{\mu_{m} S}{k_{s}} & \text { if } S<k_{s} \\
\mu_{m} & \text { if } S \geq k_{s}\end{cases} \\
\mu=\frac{\mu_{\max } S}{k_{s}+S} \\
\mu=\mu_{\max }\left(\frac{S}{k_{s}+S}\right)\left(1-\frac{C_{p}}{C_{p m}}\right)^{n}
\end{gathered}
$$

The model commonly used to describe the kinetics of microbial growth is the Monod equation, but in this study, the Monod model provided a result that was less appropriate as seen from $\mathrm{R}^{2}$ which was only 0.1638 . A study by Istianah and Gunawan (2017), the Monod equation model was also less suitable for describing the kinetics of lactic acid fermentation from sorghum flour using L. plantarum, Baker's yeast and a mixture of both with $\mathrm{R}^{2}$ of 0.6073 , 0.5638 and 0.0804 , respectively.

In this study, the best results were obtained in the Powell equation model where $\mathrm{R}^{2}$ had the highest value of 0.65913 with a maximum specific growth rate $(\mu \max )$ of 1.668/h, saturated substrate constant (Ks) of $123.4 \mathrm{~g} / \mathrm{L}$ and maintenance rate $(\mathrm{m})$ of $4.672 / \mathrm{h}$ as shown in Table 1 . The growth of $L$. casei produced metabolic products in the form of lactic acid which can be accumulated in the media. This lactic acid product can be an inhibitor in bacterial growth. Therefore, the effect of lactic acid concentration on bacterial growth was also studied in this study. In the same way as the various models above, the highest $\mathrm{R}^{2}$ results in the number of cell (n) 1.5, which was equal 
to 0.2204 . This means that formed lactic acid products can affect the rate of bacterial growth. This was also conveyed in the study of Alvarez et al. (2010), the strong inhibitory effect of lactic acid on the growth rate of biomass was characterized and explained by simple kinetic models, where specific growth rates exponentially decrease when lactic acid accumulates. The product inhibition $(\lambda)$ constant in fermentation using $L$. casei was $0.34 \mathrm{~L} / \mathrm{g}$ of lactic acid. The low $\mathrm{R}^{2}$ results because the substrate concentration (S) data was taken from the substrate reaction calculation data from time to time, so $\mathrm{S}$ has a too-small interval. This results in the calculation of kinetics having a large error. To produce high $\mathrm{R}^{2}$ in kinetics calculations, the variability substrate concentration is needed.

\section{Conclusions}

Fermentation of bitter cassava (M. glaziovii) using $L$. casei can reduce cyanide acid content, starch levels and also produce lactic acid. Therefore, modified bitter cassava flour can be used as an alternative flour to substitute wheat flour. After $40 \mathrm{~h}$ of fermentation, HCN decreased to $0.02 \mathrm{ppm}$, lactic acid increased to $0.000928 \mathrm{~g} / \mathrm{L}$, while starch decreased to $59.13 \%$, as well as amylose and amylopectin, which decreased respectively, reaching 12.98\% and $46.15 \%$. The best kinetic model that can describe the growth of $L$. casei in terms of the highest $\mathrm{R}^{2}(0.65913)$ obtained from the Powell equation. In this study, the effect of the product produced on the growth kinetics of $L$. casei by modifying the Monod equation to produce the best $\mathrm{R}^{2}$ $(0.2204)$ at an $n$ value of 1.5 was also studied. The high error in this study was because the $\mathrm{S}$ interval is too small, therefore it is necessary to do a variable on the initial substrate concentration..

\section{Acknowledgments}

The authors thank the Directorate General of Resources for Science, Technology, and Higher Education, Ministry of Education and Culture of Republic Indonesia (no. 1126/PKS/ITS/2020).

\section{Authors' contributions}

SG, HW, TW designed the study. NR, RL carried out the laboratory work. SG, NR, RL, ID analyzed the data. SG, NR, RL wrote the manuscript. All authors read and approved the final version of the manuscript.

\section{Competing interests}

The author declare that they have no competing interest.

\section{References}

Alcázar-Alay SC, Meireles MAA. 2015. Physicochemical properties, modifications and applications of starches from different botanical sources. Food Sci Technol. 35(2):215-236. doi:10.1590/1678-457X.6749.

Alvarez MM, Aguirre-Ezkauriatza EJ, Ramírez-Medrano A, Rodríguez-Sánchez Á. 2010. Kinetic analysis and mathematical modeling of growth and lactic acid production of Lactobacillus casei var. rhamnosus in milk whey. J Dairy Sci. 93(12):5552-5560. doi:10.3168/jds.2010-3116.

AOAC. 2005. Official Methods of Analysis of AOAC International. Gaithersburg, Md.: AOAC International.

Bai DM, Wei Q, Yan ZH, Zhao XM, Li XG, Xu SM. 2003. Fed-batch fermentation of Lactobacillus lactis for hyper-production of L-lactic acid. Biotechnol Lett. 25(21):1833-1835. doi:10.1023/A:1026276925649.

Farinde EO, Obatolu V, Oyarekua M, Adeniran HA, Ejoh SI, Olanipekun O. 2010. Physical and microbial properties of fruit flavoured fermented cowmilk and soy milk ( yoghurt-like ) under different temperature of storage . Afr J Food Sci. 1(5):120-127.

GEA. 2006. Analytical methods A titratable acidity. URL https://www.gea.com/en/binaries/A\%2019\%20a\%2 0-\%20Titratable\%20Acidity_tcm11-30930.pdf.

Gunawan S, Aparamarta HW, Anindita BP, Antari AT. 2019. Effect of fermentation time on the quality of modified gadung flour from gadung tuber (Dioscorea hispida Dennst.). IOP Conference Series: Materials Science and Engineering 673:012002. doi:10.1088/1757-899x/673/1/012002.

Gunawan S, Istighfarah Z, Aparamarta HW, Syarifah F, Dwitasari I. 2017. Utilization of modified cassava flour and its by-products. In: Handbook on Cassava: Production, Potential Uses and Recent Advances, chapter 14. Nova Science Publishers, Inc. p. 271-296.

Gunawan S, Widjaja T, Zullaikah S, Ernawati L, Istianah N, Aparamarta HW, Prasetyoko D. 2015. Effect of fermenting cassava with Lactobacillus plantarum, Saccharomyces cereviseae, and Rhizopus oryzae on the chemical composition of their flour. Int Food Res J. 22(3):1280-1287.

Gunawan S, Wirawasista Aparamarta H, Zarkasie IM, Prihandini WW. 2018. Effect of initial bacteria cells number and fermentation time on increasing nutritive value of sago flour. Mal J Fund Appl Sci. 14(2):246250. doi:10.11113/mjfas.v14n2.941.

Istianah N, Ernawati L, Anal AK, Gunawan S. 2018. Application of modified sorghum flour for improving bread properties and nutritional values. Int Food Res J. 25(1):166-173.

Istianah N, Gunawan S. 2017. Kinetika Fermentasi Asam Laktat dari Tepung Sorgum Menggunakan Yeast dan L. Plantarum. Jurnal Rekayasa Bahan Alam dan Energi Berkelanjutan. 1(2):49-55.

Krischke W, Schröder M, Trösch W. 1991. Continuous production of l-lactic acid from whey permeate by immobilized Lactobacillus casei subsp. casei. Appl Food Biotechnol. 34(5):573-578. doi:10.1007/BF00167901. 
Mahanta DJ, Borah M, Saikia P. 2014. Study on Kinetic Models for analysing the bacterial growth rate. AIJRSTEM 8(1):2328-3491.

Martens BM, Gerrits WJ, Bruininx EM, Schols HA. 2018. Amylopectin structure and crystallinity explains variation in digestion kinetics of starches across botanic sources in an in vitro pig model. J Anim Sci Biotechnol. 9(1). doi:10.1186/s40104-018-0303-8.

Mirdamadi S, Sadeghi H, Sharafi N, Fallahpour M, Mohseni FA, Bakhtiari MR. 2002. Comparison of lactic acid isomers produced by fungal and bacterial strains. Iran Biomed. J. 6(2-3):69-75.

Narayanan N, Roychoudhury PK, Srivastava A. 2004. Isolation of adh mutant of Lactobacillus rhamnosus for production of L(+) Lactic acid. Electron J Biotechnol. 7(1):79-91. doi:10.2225/vol7-issue1-fulltext-7.

Nebiyu A, Getachew E. 2011. Soaking and drying of cassava roots reduced cyanogenic potential of three cassava varieties at Jimma, Southwest Ethiopia. Afr J Biotechnol. 10(62):13465-13469. doi:10.5897/ajb10.2636.

Panesar PS, Kennedy JF, Knill CJ, Kosseva M. 2010. Production of L(+) Lactic Acid using Lactobacillus casei from Whey. Braz Arch Biol Technol. 53(1):219-226. doi:10.1590/S1516-89132010000100027.

Rezvani F, Ardestani F, Najafpour G. 2017. Growth kinetic models of five species of Lactobacilli and lactose consumption in batch submerged culture. Braz J Microbiol. 48(2):251-258. doi:10.1016/j.bjm.2016.12.007.

Setiarto RHB, Nunuk W. 2017. Effect of Lactic Acid Bacteria Fermentation and Autoclaving-Cooling Cycle for The Level of Resistant Starch of Modified Purple Sweet Potato Flour (Ipomea Batatas Var Ayamurasaki). Warta IHP. 34(1):26-35.

SNI. 2011. Modified cassava flour.

Solomons TWG, Craig BF. 2011. Organic Chemistry. 10th Edition. New Jersey: John Wiley \& Sons, Inc.

Suharyono S, Rizal S, Kurniadi M, et al. 2012. Pertumbuhan $L$. casei pada berbagai lama fermentasi minuman sinbiotik dari ekstrak cincau hijau (Premna oblongifolia Merr.). Jurnal Teknologi Hasil Pertanian. 5(2):117-128. doi:10.20961/jthp.v0i0.13564.

Taleghani HG, Najafpour GD, Ghoreyshi AA. 2016. A study on the effect of parameters on lactic acid production from whey. Pol J Chem Technol. 18(1):5863. doi:10.1515/pjct-2016-0010.

Zacharof M, Lovitt R, Ratanapongleka K, et al. 2009. Optimization of Growth Conditions for Intensive Propagation, Growth Development and Lactic Acid Production of Selected Strains of'Lactobacilli'. Engineering Our Future: Are We up to the Challenge?: 2730 September 2009, Burswood Entertainment Complex p. 1830-1839. 